\title{
CYCLIC AMP-GENERATING SYSTEMS: REGIONAL DIFFERENCES IN ACTIVATION BY ADRENERGIC RECEPTORS IN RAT BRAIN
}

\author{
J. W. DALY,* W. PADGETT, ${ }^{*}$ C. R. CREVELING, ${ }^{*}$ D. CANTACUZENE, $\ddagger$ AND K. L. KIRK $\ddagger$ \\ * Laboratory of Bioorganic Chemistry, and $\Varangle$ Laboratory of Chemistry, National Institute of Arthritis, Metabolism and Digestive Diseases, \\ National Institutes of Health, Bethesda, Maryland 20205
}

\begin{abstract}
Catecholamine, histamine, and adenosine-mediated accumulations of radioactive cyclic AMP were assessed in adenine-labeled slices from eight rat brain regions. 2-Fluoronorepinephrine, a selective $\beta$ adrenergic agonist, elicited an accumulation of cyclic AMP in cerebral cortex, cerebellum, hippocampus, striatum, superior colliculi, thalamus, hypothalamus, and medulla-pons. In cerebral cortex and most other brain regions, the $\beta$-adrenergic-mediated response appeared to involve primarily $\beta_{1}$-adrenergic receptors, while in cerebellum, there was a significant involvement of $\beta_{z}$-adrenergic receptors. 6 -Fluoronorepinephrine, a selective $\alpha$-adrenergic agonist, elicited accumulations of cyclic AMP in all regions except cerebellum. Combinations of the two fluoro derivatives afforded in all brain regions an accumulation of cyclic AMP identical with that elicited by norepinephrine. In hypothalamus, the $\alpha$ - and $\beta$-adrenergic responses were significantly greater than additive. In cerebral cortex, the $\alpha$-adrenergic receptor-mediated response appeared to involve $\alpha_{1}$-adrenergic receptors and to be nearly completely dependent on adenosine, while in other brain regions, the dependence of the $\alpha$-adrenergic response on adenosine was less or absent. Combinations of 6 fluoronorepinephrine and histamine had greater than additive effects in cortex and hippocampus. The results indicate that the interactive control of cyclic AMP-generating systems by $\alpha$-adrenergic, $\beta$-adrenergic, adenosine, and histamine receptors differs significantly among rat brain regions.
\end{abstract}

The regulation of cyclic AMP levels by catecholamines in the central nervous system appears to involve rather unique and certainly complex interactions of $\alpha$ - and $\beta$ adrenergic receptors, adenosine, prostaglandins, and calcium ions. Activation of $\alpha$-adrenergic receptors leads to marked accumulations of cyclic AMP in brain tissue (Daly, 1977 and references therein), which is remarkable since in most tissues, $\alpha$-adrenergic agonists are inhibitory to cyclic AMP-generating systems (cf., McCarthy and deVellis, 1978; Sabol and Nirenberg, 1979). It has been proposed that activation of $\alpha$-adrenergic receptors in brain tissue merely facilitates $\beta$-adrenergic, $\mathrm{H}_{2}$-histaminergic, and $\mathrm{A}_{2}$-adenosinergic receptor-mediated activation of adenylate cyclase (Daly et al., 1980). The stimulatory $\alpha$-adrenergic response appears strongly dependent on the presence of extracellular calcium ions (Schwabe and Daly, 1977), adenosine (Sattin et al., 1975; Daly et al., 1980), and prostaglandins of the $\mathbf{E}$ series (Partington et al., 1980). Such unique and complex regulatory interactions have been investigated thoroughly only in rodent cerebral cortical slices and there has been limited investigation of the adrenergic responses in other brain regions (Table I). The presence of $\alpha$-adrenergic receptor-mediated activation of cyclic AMP systems and its interaction with $\beta$-adrenergic-sensitive, adenosine-sensitive, and histamine-sensitive cyclic AMP systems have now been surveyed in eight rat brain regions using a specific $\alpha$ - adrenergic agonist, 6-fluoronorepinephrine, and a specific $\beta$-adrenergic agonist, 2-fluoronorepinephrine (Daly et al., 1980 ), both alone, in combination, and in consort with histamine or adenosine.

\section{Materials and Methods}

Materials. dl-2-Fluoro- and 6-fluoronorepinephrine were prepared essentially as described (Kirk et al., 1979). $d l$-Isoproterenol $\cdot \mathrm{HCl}$, yohimbine $\cdot \mathrm{HCl}, d l$-propranolol . $\mathrm{HCl}$, adenosine, 2-chloroadenosine, and adenosine deaminase were from Sigma Chemical Co., St. Louis, MO; phenoxybenzamine $\cdot \mathrm{HCl}$ from Smith Kline and French Laboratories, Philadelphia, PA; $d l$-norepinephrine $\cdot \mathrm{HCl}$, $l$-phenylephrine, and 8-phenyltheophylline from Calbiochem Corp., San Diego, CA; butoxamine. $\mathrm{HCl}$ from Burroughs Wellcome Co., Research Triangle Park, NC; practolol from Ayerst Laboratories, Inc., New York, NY; phentolamine $\cdot \mathrm{HCl}$, naphazoline $\cdot \mathrm{HCl}$, and metoprolol from CIBA-Geigy Corp., Ardsley, NY; prazosin. $\mathrm{HCl}$ from Pfizer, Inc., Groton, $\mathrm{CO}$; clonidine $\cdot \mathrm{HCl}$ from $\mathrm{C}$. $\mathrm{H}$. Boehringer and Sohn, Ingelheim, Germany; and $\left[{ }^{3} \mathrm{II}\right]$ adenine from New England Nuclear, Boston, MA. Piperoxan was provided by Dr. N. Thoa, National Institute of Mental Health, Bethesda, MD; $2-\left[\left(2^{\prime}, 6^{\prime}\right.\right.$-dimethoxy)phenoxyethylamino]methylbenzodioxane (WB4101) by Dr. J. N. Davis, Duke University, Durham, NC; and (tert-butylamino-3-hydroxyl-2-propyl) oximino-9-flu- 
TABLE I

Adrenergic receptor-mediated accumulations of cyclic AMP in rat brain slices: Relative contributions of $\alpha$-and $\beta$-adrenergic mechanisms to accumulations of cyclic AMP elicited by catecholamines

\begin{tabular}{lcc}
\hline Brain Region & $\begin{array}{c}\text { Cyclic AMP } \\
\text { Response to } \\
\text { Catechola- } \\
\text { mine }\end{array}$ & \multicolumn{1}{c}{ References } \\
\cline { 2 - 3 } & $\begin{array}{c}\text { Adrenergic } \\
\text { Receptor } \\
\text { Type }\end{array}$ & \\
\hline Cerebral cortex ${ }^{a}$ & $\beta>\alpha$ & $\begin{array}{c}\text { Huang et al., 1973; Perkins and } \\
\text { Moore, 1973; Schultz and } \\
\text { Daly, 1973a; Skolnick and } \\
\text { Daly, 1975, 1976 }\end{array}$ \\
& &
\end{tabular}

$\quad$ Cerebellum $^{b} \quad \begin{aligned} & \text { Palmer et al., 1973; Skolnick et } \\ & \text { al., 1976; Schwabe and Daly, } \\ & 1977\end{aligned}$

$\begin{array}{cc}\text { Hypothalamus }^{c} & \alpha, \beta \quad \begin{array}{l}\text { Palmer et al., 1973; Weissman } \\ \text { et al., 1975; Badger and Ci- } \\ \text { cero, 1977 }\end{array}\end{array}$

$\begin{array}{lcc}\text { Striatum } & \beta & \text { Forn et al., 1971; Harris, } 1976 \\ \text { Limbic forebrain }^{c} & \alpha, \beta & \begin{array}{c}\text { Vetulani et al., 1977; Mobley } \\ \text { and Sulser, 1979 }\end{array}\end{array}$

$\begin{array}{ccc}\text { Brain stem } & & \\ \text { C-1 } & \beta>\alpha & \text { Wilkening et al., } 1980 \\ \text { C-2 } & \alpha & \text { Wilkening et al., } 1980\end{array}$

Spinal cord $\quad \alpha>\beta \quad$ Jones and McKenna, 1980a, b

" In guinea pig cerebral cortical slices and in hippocampal and amygdalal slices, the response appears mediated virtually entirely by $\alpha$ adrenergic receptors (Chasin et al., 1971, 1973; Schultz and Daly, 1973b; Sattin et al., 1975; Daly et al., 1980). In mouse cerebral cortical slices, the $\beta$-adrenergic component is much greater than the $\alpha$-adrenergic component (Schultz and Daly, 1973a), while in human (Kodama et al., 1973) and chicken cerebral slices (Nahorski et al., 1975), only a $\beta$ adrenergic component was detected.

${ }^{b}$ In guinea pig (Chasin et al., 1971) and rabbit (Kakiuchi and Rall, 1968) cerebellar slices, only a $\beta$-adrenergic component was detected, while in mouse cercbcllar slices, the response to norepinephrine was blocked completely by either $\alpha$ - or $\beta$-adrenergic antagonists (Ferrendelli et al., 1975).

' In rat hypothalamic slices, the response to catecholamines was blocked completely by either $\alpha$ - or $\beta$-adrenergic antagonists (Palmer et al., 1973) although in a later study, only partial blockade pertained with propranolol or phenoxybenzamine (Badger and Cicero, 1977).

${ }^{d}$ In a "microsac" preparation from rat limbic forebrain, both $\alpha$ - and $\beta$-adrenergic components contributed to cyclic AMP formation (Horn and Phillipson, 1976).

orene hydrochloride (IPS 339) by Dr. B. Petrack, CIBAGeigy Corp., Ardsley, NY. All other materials were obtained from standard commercial sources. Male SpragueDawley rats ( 175 to $225 \mathrm{gm}$ ) were obtained from Taconic Farms, Germantown, NY.

The Krebs-Ringer bicarbonate/glucose buffer contained $122 \mathrm{mM} \mathrm{NaCl}, 3 \mathrm{mM} \mathrm{KCl}, 1.2 \mathrm{mM} \mathrm{MgSO}_{4}, 1.3 \mathrm{mM}$ $\mathrm{CaCl}_{2}, 0.4 \mathrm{mM} \mathrm{KH}_{2} \mathrm{PO}_{4}, 10 \mathrm{mM}$ glucose, and $25 \mathrm{~mm}$ $\mathrm{NaHCO}_{3}$. All incubations in Krebs-Ringer buffer were done with constant aeration with $95 \% \mathrm{O}_{2}, 5 \% \mathrm{CO}_{2}$.
Assay of cyclic AMP generation in rat brain slices. Rats were sacrificed by decapitation, the brains were removed quickly, chilled in ice cold oxygenated KrebsRinger buffer, and dissected on a chilled glass plate, and the dissected tissue was placed in another beaker of chilled buffer. Strips of cerebral cortical gray matter from three brains, cerebellar gray matter from five brains, hippocampus from seven brains, striatum from 20 brains, superior colliculi from 20 brains, thalamus from 20 brains, hypothalamus from 20 brains, or medulla-pons from five brains were cut on a cooled Mcllwain tissue slicer set at $260 \mu \mathrm{m}$, the axis of the slicing block was rotated $180^{\circ}$ and the tissue was sliced again. Then, the tissue slices were transferred to a beaker containing $15 \mathrm{ml}$ of buffer aerated with $95 \% \mathrm{O}_{2}, 5 \% \mathrm{CO}_{2}$ at $37^{\circ} \mathrm{C}$ and incubated for $15 \mathrm{~min}$.

The preincubated brain slices were decanted onto a piece of nylon mesh and quickly transferred to a beaker containing $10 \mathrm{ml}$ of buffer containing adenine $(30 \mu \mathrm{M})$ and $\left[{ }^{3} \mathrm{H}\right]$ adenine (20 to $60 \mu \mathrm{Ci}$ ) and incubated for $40 \mathrm{~min}$ at $37^{\circ} \mathrm{C}$ while gently gassed with $95 \% \mathrm{O}_{2}, 5 \% \mathrm{CO}_{2}$. The Krebs-Ringer buffer was decanted, and the slices were washed twice with buffer and incubated for an additional $15 \mathrm{~min}$ in fresh buffer. Next, the buffer was decanted, and the tissue was collected on nylon mesh, divided into 12 to 14 approximately equal portions, and transferred with a stainless steel spatula to $30-\mathrm{ml}$ beakers containing 10 $\mathrm{ml}$ of buffer and allowed to equilibrate for $5 \mathrm{~min}$. Agents were added in appropriate concentrations from solutions in prewarmed, gassed buffer. After incubation for $10 \mathrm{~min}$, unless otherwise stated, the buffer was decanted, and the lissue was collected on nylon mesh, transferred to conical homogenizing tubes containing $1 \mathrm{ml}$ of $6 \%$ trichloroacetic acid and unlabeled cyclic AMP $(0.25 \mu \mathrm{mol})$, and homogenized with a glass pestle. The homogenates were centrifuged for $10 \mathrm{~min}$ at $2000 \mathrm{rpm}$. An aliquot of the trichloroacetic acid supernatant fraction $(0.05 \mathrm{ml})$ was removed and the radioactivity was measured. The cyclic $\left[{ }^{3} \mathrm{H}\right] \mathrm{AMP}$ formed was determined in the remaining supernatant fraction by the double column method of Salomon et al. (1974). Protein was determined by the Miller (1959) adaptation of the method of Lowry et al. (1951) as further adapted for an autoanalyzer. Results are expressed as percentage of total radioactive nucleotides present as cyclic AMP (\% conversion). This prelabeling technique, originally described by Shimizu et al. (1969), has afforded results completely consonant with results based on measurement of endogenous levels of cyclic AMP in brain slices (cf., Daly, 1977). An incubation time of $10 \mathrm{~min}$ affords stable maximal levels of cyclic AMP with virtually all agonists so far investigated in brain slices. Statistical analysis was with the Student's $t$ test.

\section{Results}

Selective effects of fluoronorepinephrines on $\alpha$ - and $\beta$-adrenergic receptors in rat brain slices. 2-Fluoronorepinephrine and 6-fluoronorepinephrine appear to represent a selective $\beta$-adrenergic and a selective $\alpha$-adrenergic agonist, respectively, with respect to cyclic AMP-generating systems in slices from rat cerebral cortex (Daly et al., 1980). The maximal response to 2-fluoronorepinephrine is equivalent to that of isoproterenol (Table II), while the response to 6 -fluoronorepinephrine 


\section{TABLE II}

Accumulations of radioactive cyclic AMP elicited in adenine-labeled slices of rat cerehral cortex by catecholamines

Slices were incubated for $10 \mathrm{~min}$ with $100 \mu \mathrm{M}$ concentrations of catecholamines and accumulations of cyclic $\left[{ }^{3} \mathrm{H}\right] \mathrm{AMP}$ measured as detailed under "Materials and Methods." Results are means \pm SEM for 5 to 10 experiments.

\begin{tabular}{lc}
\hline \multicolumn{1}{c}{ Agonist } & Radioactive Cyclic AMP \\
\hline & \% conversion \\
None & $0.19 \pm 0.01$ \\
Norepinephrine & $3.29 \pm 0.02$ \\
Isoproterenol & $1.40 \pm 0.13$ \\
2-Fluoronorepinephrine & $1.56 \pm 0.17$ \\
6-Fluoronorepinephrine & $0.60 \pm 0.06$ \\
\hline
\end{tabular}

is much lower and is equivalent to that elicited by a norepinephrine-propranolol combination (Table II, Daly et al., 1980). The response to 2-fluoronorepinephrine is nearly maximal at $10 \mu \mathrm{M}$, with an $\mathrm{EC}_{50}$ of about $5 \mu \mathrm{M}$ (Fig. 1). Phentolamine (10 $\mu \mathrm{M})$ has virtually no effect on the response, while propranolol $(10 \mu \mathrm{M})$ completely blocks the response elicited by 10 to $100 \mu \mathrm{M} 2$-fluoronorepinephrine. The response to 6-fluoronorepinephrine does not reach a maximum even at $200 \mu \mathrm{M}$ (Fig. 2). However, this appears to be due primarily to the emergence of a $\beta$-adrenergic component at concentrations above $100 \mu \mathrm{M}$. Thus, when a dose-response curve is generated in the presence of propranolol, the response to 6 -fluoronorepinephrine is nearly maximal at $50 \mu \mathrm{M}$ with an $\mathrm{EC}_{50}$ of about $30 \mu \mathrm{M}$. Furthermore, in the range of 10 to $50 \mu \mathrm{M}$ 6-fluoronorepinephrine, propranolol has no effect on the response, while phentolamine blocks the response completely. It would appear that 6 -fluoronorepinephrine can be employed as a selective $\alpha$-adrenergic agonist in brain slices only in concentrations of $100 \mu \mathrm{M}$ or less. In rat cerebral cortex, the stimulation of cyclic AMP systems by the $\alpha$-adrenergic agonist 6 -fluoronorepinephrine was completely dependent on adenosine receptor activation, since a potent adenosine antagonist, 8-phenyltheophylline, blocked the response (Table III). The responses to $\beta$ agonists such as isoproterenol and 2fluoronorepinephrine were not reduced by 8-phenyltheophylline, while the response to norepinephrine was reduced in magnitude $(p<0.05)$. The responses of cyclic AMP systems to norepinephrine, the fluoronorepinephrines, and isoproterenol now were examined in eight rat brain regions.

Cerebral cortex. Norepinephrine elicited an accumulation of cyclic AMP in rat cerebral cortical slices which was significantly greater $(p<0.01)$ than the response to 2 -fluoronorepinephrine (Fig. $3 B$ ). A combination of 2fluoronorepinephrine and 6-fluoronorepinephrine elicited an accumulation of cyclic AMP equal to that elicited by norepinephrine. The response to combinations of 2 and 6-fluoronorepinephrine was often greater than additive. However, it was not found to be significantly greater than additive $(p>0.2)$. The presence of adenosine deaminase significantly reduced the responses to norepinephrine $(p<0.001)$ in rat cerebral cortical slices and slightly reduced the response to 2-fluoronorepinephrine $(p<0.1)$. The response to 6 -fluoronorepinephrine was no longer significant in the presence of adenosine deam-

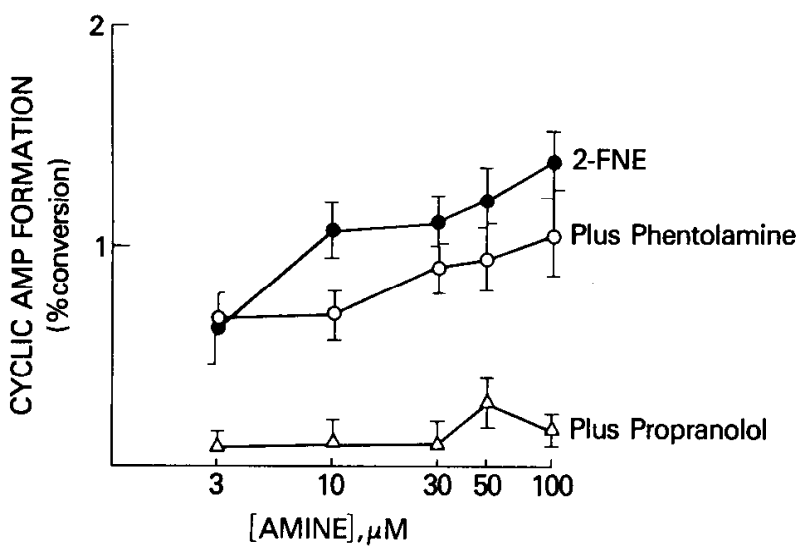

Figure $1{ }^{1}$ Dose-response relationships for 2-fluoronorepinephrine-elicited accumulations of radioactive cyclic AMP in adenine-labeled rat cerebral cortical slices. Slices were incubated for $10 \mathrm{~min}$ with varying concentrations of 2 -fluoronorepinephrine and accumulations of cyclic $\left[{ }^{3} \mathrm{H}\right] \mathrm{AMP}$ measured as detailed under "Materials and Methods." Incubations were catecholamine alone (O); in the presence of an $\alpha$-antagonist, phentolamine $(O, 10 \mu \mathrm{M})$; or in the presence of a $\beta$-antagonist, propranolol $(\triangle, 10 \mu \mathrm{M})$. Antagonists were added 2 min prior to the catecholamine. Values are means \pm SEM for six experiments.

inase $(p>0.2)$. The response to adenosine was significantly potentiated by 6 -fluoronorepinephrine in rat cerebral cortical slices (Fig. $4, p<0.05$ ). The small but significant response to histamine $(p<0.025)$ was greater than additive with the response to 6-fluoronorepinephrine $(p<0.05)$. It would appear that potentiative interactions of $\alpha$-adrenergic receptor mechanisms with classes of stimulatory receptors are an important characteristic of cyclic AMP systems in cerebral cortical slices. The accumulation of cyclic AMP elicited by norepinephrine and 2-chloroadenosine in the presence of adenosine deaminase was slightly greater than additive (Fig. 5, $p<0.05$ ).

The $\alpha$-adrenergic response of cyclic AMP systems in rat cerebral cortical slices to a norepinephrine-propranolol combination was blocked by a variety of $\alpha$-adrenergic antagonists (Fig. 6). The potency of various compounds in blocking the response to the norepinephrine-propranolol combination was as follows:

$$
\begin{gathered}
\text { prazosin }>\text { WB 4101, phentolamine, clonidine }>\text { naphazoline, } \\
\text { piperoxan }>\text { yohimbine }
\end{gathered}
$$

Thus, the most potent blockers were the very selective $\alpha_{1}$-antagonists, prazosin and WB 4101 (Langer, 1977), while the least potent blockers were the selective $\alpha_{2^{-}}$ antagonists, piperoxan and yohimbine (Langer, 1977). Clearly, the $\alpha$-adrenergic receptors involved in activation of cyclic AMP systems in cerebral cortical slices would appear to exhibit properties characteristic of $\alpha_{1}$-adrenergic receptors, namely blockade by prazosin and WB 4101 . Prazosin is remarkably selective for $\alpha_{1}$-adrenergic recep-

\footnotetext{
${ }^{1}$ The abbreviations used on the figures are: Ads, adenosine; 2-FNE, 2-fluoronorepinephrine; 6-FNE, 6-fluoronorepinephrine; HN, histamine.
} 


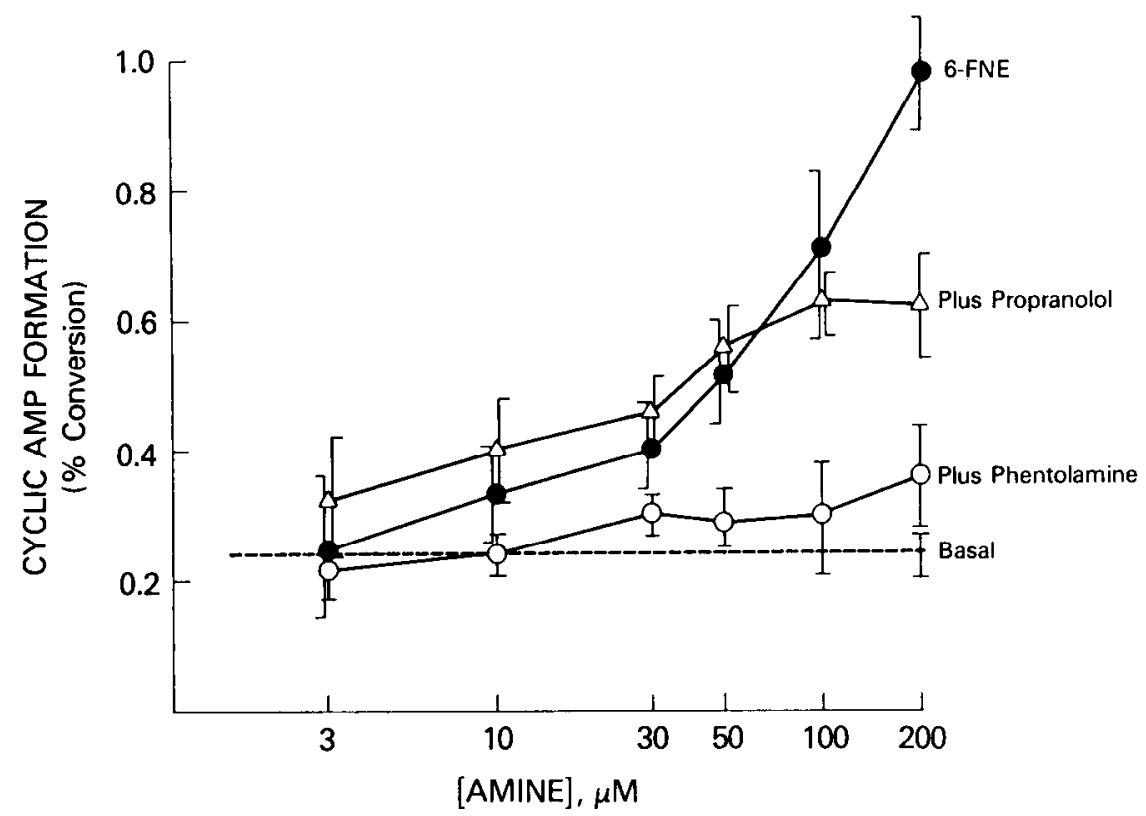

Figure 2. Dose-response relationships for 6-fluoronorepinephrine-elicited accumulations of radioactive cyclic AMP in adenine-labeled rat cerebral cortical slices. Slices were incubated for $10 \mathrm{~min}$ with varying concentrations of 6-fluoronorepinephrine and accumulations of cyclic $\left[{ }^{3} \mathrm{H}\right] \mathrm{AMP}$ were measured as detailed under "Materials and Methods." Incubations were catecholamine alone (O); in the presence of an $\alpha$-antagonist, phentolamine $(O, 10 \mu \mathrm{M})$; or in the presence of a $\beta$-antagonist, propranolol $(\triangle, 10 \mu \mathrm{M})$. Antagonists were added $2 \mathrm{~min}$ prior to the catecholamine. Values are means \pm SEM for six experiments.

TABLE III

Accumulations of cyclic $\left[{ }^{3} H\right] A M P$ elicited in adenine-labeled slices of rat cerebrul cortex by catecholamines in the presence of a potent adenosine antagonist, 8-phenyltheophylline

Slices were incubated with catecholamines at $100 \mu \mathrm{M}$ concentrations in the presence and absence of 8-phenyltheophylline $(10 \mu \mathrm{M})$ for $10 \mathrm{~min}$ and accumulations of cyclic $\left[{ }^{3} \mathrm{H}\right] \mathrm{AMP}$ were measured as detailed under "Materials and Methods." Results are means \pm SEM for three experiments.

\begin{tabular}{lcc}
\hline \multicolumn{1}{c}{ Catecholamine } & $\begin{array}{c}\text { 8-Phenyl- } \\
\text { theo- } \\
\text { phylline }\end{array}$ & Cyclic ["H]AMP Formation \\
\hline \multirow{2}{*}{ None } & - & $\%$ conversion \\
Norepinephrine & + & $0.16 \pm 0.02$ \\
Isoproterenol & - & $0.13 \pm 0.01$ \\
2-Fluoronorepinephrine & + & $3.10 \pm 0.30$ \\
& - & $2.10 \pm 0.30$ \\
6-Fluoronorepinephrine & + & $1.10 \pm 0.20$ \\
& + & $1.30 \pm 0.30$ \\
& - & $1.10 \pm 0.30$ \\
& + & $1.60 \pm 0.10$ \\
& + & $0.41 \pm 0.05$ \\
& & $0.17 \pm 0.03^{a}$
\end{tabular}

${ }^{a}$ Not significantly greater than control $p>0.1$.

tors in brain membranes (U'Prichard et al., 1978b). Furthermore, since piperoxan and yohimbine are not particularly selective ligands for central $\alpha_{1}$ - and $\alpha_{2}$-adrenergic receptors (U'Prichard et al., 1977), it appears likely that the blockade of responses to the norepinephrine-propranolol combinations in rat cerebral cortical slices by high concentrations of these compounds involves blockade of $\alpha_{1}$-adrenergic receptors rather than providing evidence for involvement of $\alpha_{2}$-adrenergic receptors. However, it is also clear that the central $\alpha$-adrenergic receptors involved in control of cyclic AMP are unique. Thus, the $\alpha_{z}$-adrenergic agonists, clonidine and naphazoline (Langer, 1977), act as antagonists rather than as agonists (Fig. 6. Skolnick and Daly, 1975). Clonidine and naphazoline are highly selective ligands for the $\alpha_{2}$-adrenergic receptor in brain membranes (U'Prichard et al., 1977), but it would appear the concentrations required to block the $\alpha$-adrenergic response in cortical slices (Fig. 6) are far greater than the expected for interaction with an $\alpha_{2-}$ adrenergic receptor. The estimated $\mathrm{IC}_{50}$ values of the various antagonists versus the response of cyclic AMP systems to $30 \mu \mathrm{M}$ 6-fluoronorepinephrine in rat cerebral cortical slices were as follows:

$$
\begin{gathered}
\text { prazosin }(0.05 \mu \mathrm{M})>\text { WB } 4101(0.3 \mu \mathrm{M})>\text { piperoxan }(1 \mu \mathrm{M})> \\
\text { phentolamine }(2 \mu \mathrm{M})>\text { yohimbine }(5 \mu \mathrm{M})
\end{gathered}
$$

(data not shown). Propranolol at $10 \mu \mathrm{M}$ and practolol or butoxamine at $100 \mu \mathrm{M}$ had no significant effect on the response to 6-fluoronorepinephrine. It should be noted that in binding studies with rat cerebral cortical membranes, 6 -fluoronorepinephrine, like norepinephrine, has higher affinity for $\alpha_{2}$ - than for $\alpha_{1}$-adrenergic receptors (Nimit et al., 1980).

The $\beta$-adrenergic response to isoproterenol in rat cerebral cortical slices was blocked completely by $100 \mu \mathrm{M}$ practolol or $10 \mu \mathrm{M}$ propranolol while being virtually unaffected by $100 \mu \mathrm{M}$ butoxamine (Fig. $7 \mathrm{C}$ ). Thus, a relatively specific $\beta_{1}$-adrenergic antagonist, practolol (cf., U'Prichard et al., 1978a), is quite effective in blocking the 


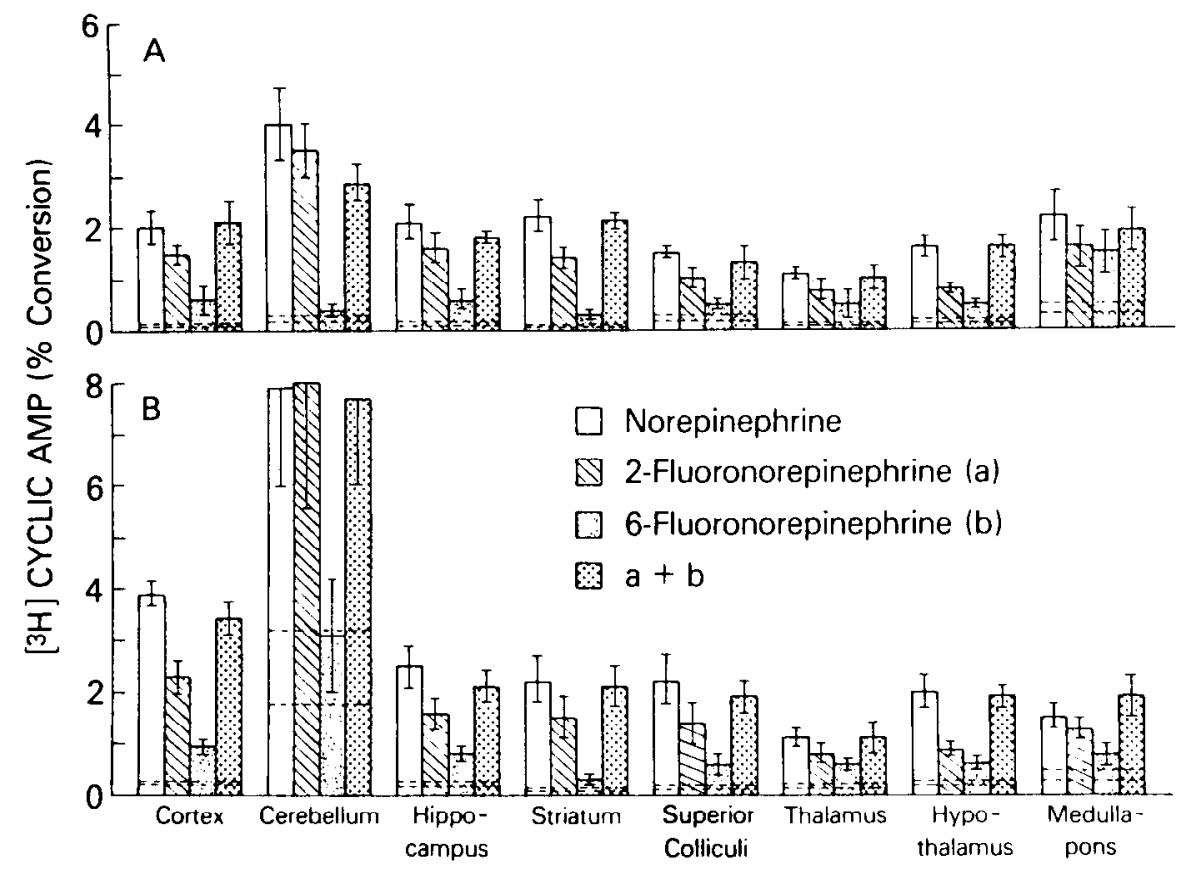

Figure 3. Effect of catecholamines on accumulations of radioactive cyclic AMP in adenine-labeled rat brain slices. Slices were incubated for $10 \mathrm{~min}$ with norepinephrine, 2-fluoronorepinephrine $(a)$, 6-fluoronorepinephrine $(b)$, or a combination of 2 and 6-fluoronorepinephrine $(a+b)$ and accumulations of cyclic [ $\left.{ }^{3} \mathrm{H}\right] \mathrm{AMP}$ were measured as detailed under "Materials and Methods." The amines were present at $100 \mu \mathrm{M}$. $A$, Adenosine deaminase $(10 \mu \mathrm{g} / \mathrm{ml})$ added $2 \mathrm{~min}$ prior to catecholamine. $B$, Control. Values are means \pm SEM for three to seven experiments. Basal values are indicated by the horizontal dashed lines (upper line is the mean + SEM, lower line is the mean - SEM). Statistical significance of difference is discussed in the text.

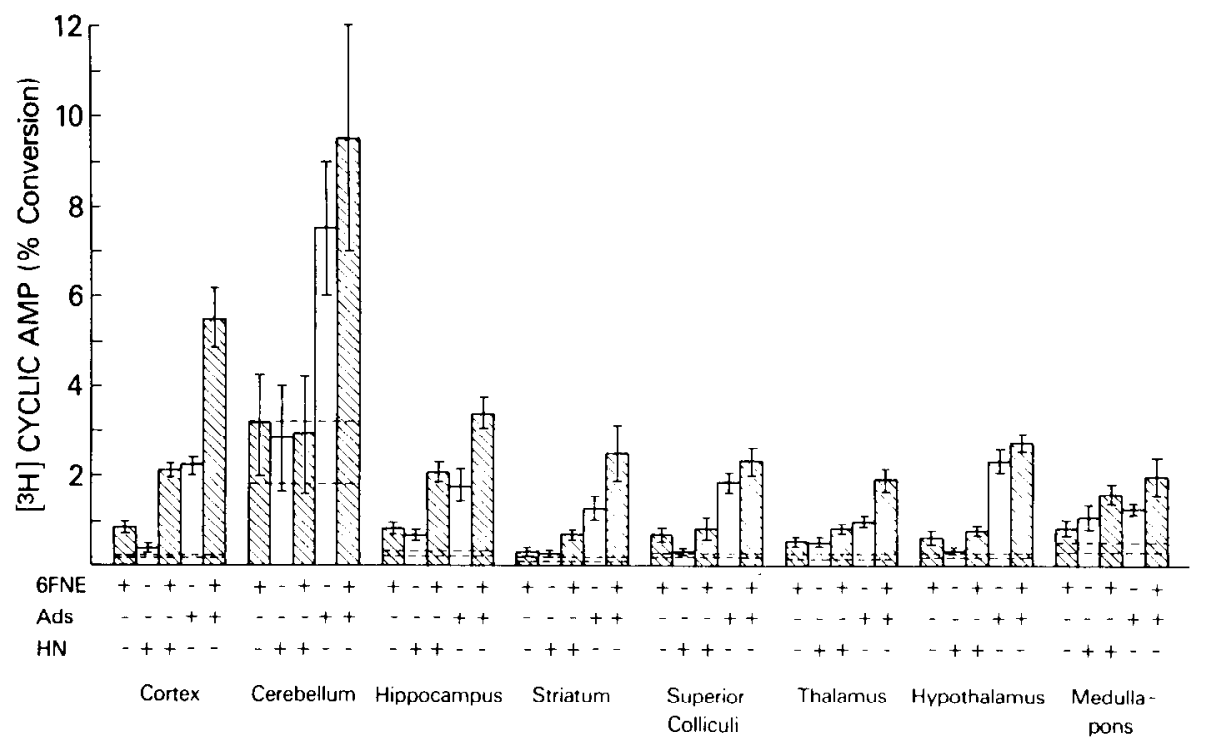

Figure 4. Effect of 6-fluoronorepinephrine with histamine or adenosine on accumulations of radioactive cyclic AMP in adenine-labeled rat brain slices. Slices were incubated for $10 \mathrm{~min}$ with 6-fluoronorepinephrine, histamine, adenosine, or combinations of agents and accumulations of cyclic [ $\left.{ }^{3} \mathrm{H}\right]$ AMP were measured as detailed under "Materials and Methods." All agents were present at $100 \mu \mathrm{M}$. Values are means \pm SEM for three experiments. Basal values are indicated by the horizontal dashed lines (see legend to Fig. 3). Statistical significance of differences is discussed in the text. 


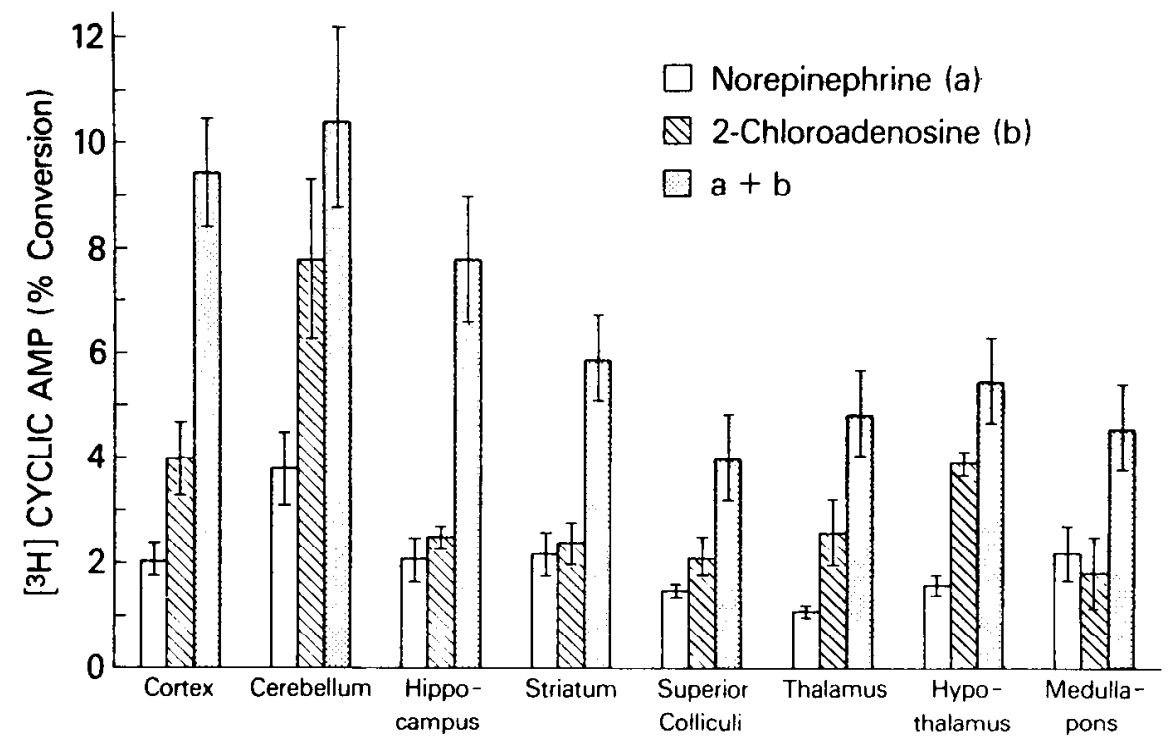

Figure 5. Effect of norepinephrine and 2-chloroadenosine on accumulations of radioactive cyclic AMP in adenine-labeled rat brain slices. Slices were incubated for $10 \mathrm{~min}$ with norepinephrine $(a), 2$-chloroadenosine $(b)$, or a combination of norepinephrine and 2-chloroadenosine $(a+b)$ and accumulations of cyclic [ $\left.{ }^{3} \mathrm{H}\right] \mathrm{AMP}$ were measured as detailed under "Materials and Methods." Stimulatory agents were present at $100 \mu \mathrm{M}$ and adenosine deaminase $(10 \mu \mathrm{g} / \mathrm{ml})$ was added 2 min prior to the stimulatory agent. Values are means \pm SEM for three experiments. For basal values see Fig. $3 A$. Statistical significance of differences is discussed in the text.

response to isoproterenol, while a relatively specific $\beta_{2-}$ adrenergic antagonist, butoxamine, has little effect. Another $\beta_{1}$-adrenergic antagonist, metoprolol (cf., Minneman et al., 1979), at $10 \mu \mathrm{M}$ blocked the isoproterenol response by $60 \%$, while another $\beta_{2}$-adrenergic antagonist, IPS 339 (Leclerc et al., 1977), at $10 \mu \mathrm{M}$ had no significant effect (data not shown). However, at $100 \mu \mathrm{M}$, IPS 339 did cause a $60 \%$ inhibition of the isoproterenol response. The results indicate that $\beta_{1}$-adrenergic receptors are predominant in control of cyclic AMP systems in rat cerebral cortex in agreement with binding data on the nature of $\beta$-adrenergic receptors in rat cerebral cortical membranes (Minneman et al., 1979). The response to $30 \mu \mathrm{M} 2$-fluoronorepinephrine was markedly antagonized by $10 \mu \mathrm{M}$ propranolol and $100 \mu \mathrm{M}$ practolol but only slightly affected by $100 \mu \mathrm{M}$ butoxamine (Fig. 7A) or by $\alpha$-antagonists such as phentolamine, prazosin, piperoxan, or yohimbine, each at $10 \mu \mathrm{M}$ (data not shown). Another $\beta_{1}$ adrenergic antagonist, metoprolol, at $10 \mu \mathrm{M}$ blocked the response to 2 -fluoronorepinephrine by $90 \%$. It should be noted that in binding studies with rat brain membranes 2 -fluoronorepinephrine has about a 10 -fold higher affinity for $\beta_{1}$ - than for $\beta_{2}$-adrenergic receptors (Nimit et al., 1980 ), while isoproterenol is equipotent at both types of central receptors (cf., U'Prichard et al., 1978b). The $\mathrm{IC}_{50}$ values versus $30 \mu \mathrm{M} 2$-fluoronorepinephrine in rat cerebral cortical slices were estimated as follows:

propranolol $(0.5 \mu \mathrm{M})>$ practolol $(20 \mu \mathrm{M})>>$ butoxamine $(>200 \mu \mathrm{M})$

(data not shown). $\beta_{1}$-Adrenergic receptors have been shown recently to be primarily involved in activation of adenylate cyclase in cat cerebral cortical membranes (Dolphin et al., 1979). In chicken cerebral slices, the receptor-mediating cyclic AMP accumulations appeared to have $\beta_{2}$-adrenergic character (Nahorski and Smith, 1977).

Cerebellum. In rat cerebellar slices, very high and variable basal values for cyclic AMP render difficult the investigation of receptors controlling cyclic AMP systems (cf., Daly, 1977). The presence of adenosine deaminase causes a profound reduction and stabilization of basal values of cyclic AMP in cerebellar slices (Fig. 3, $A$ and $B$ ). Responses to norepinephrine and 2-fluoronorepinephrine were nearly equivalent in rat cerebellar slices. 6Fluoronorepinephrine had no effect in the presence or absence of adenosine deaminase (Fig. $3, A$ and $B$ ) nor did 6-fluoronorepinephrine increase the response to adenosine (Fig. 4). Histamine had no effect on cyclic AMP levels in the presence or absence of 6-fluoronorepinephrine. Responses to a combination of norepinephrine and 2-chloroadenosine were not greater than additive (Fig. 5). There appeared to be a tendency for 6fluoronorepinephrine to reduce the response to 2-fluoronorepinephrine but this was not significant $(p>0.5)$.

Isoproterenol elicited an accumulation of cyclic AMP which was not significantly greater than that elicited by norepinephrine (data not shown). Propranolol at $10 \mu \mathrm{M}$ blocked the response to isoproterenol completely, while butoxamine at $100 \mu \mathrm{M}$ caused a $30 \%$ reduction and practolol had no effect (Fig. $7 D$ ). Another $\beta_{2}$-adrenergic antagonist, IPS 339 , at 10 and $100 \mu \mathrm{M}$ blocked the response to $10 \mu \mathrm{M}$ isoproterenol by 35 and $60 \%$, respectively (data not shown). Another $\beta_{1}$-adrenergic antagonist, metoprolol, at $10 \mu \mathrm{M}$ had no effect on the isoproterenol response, while at $100 \mu \mathrm{M}$ metoprolol, a $30 \%$ blockade was manifest. It thus appeared that unlike cerebral cortical slices, both $\beta_{1}$ - and $\beta_{2}$-adrenergic receptors were involved in control of cyclic AMP systems in cerebellar slices. The response 


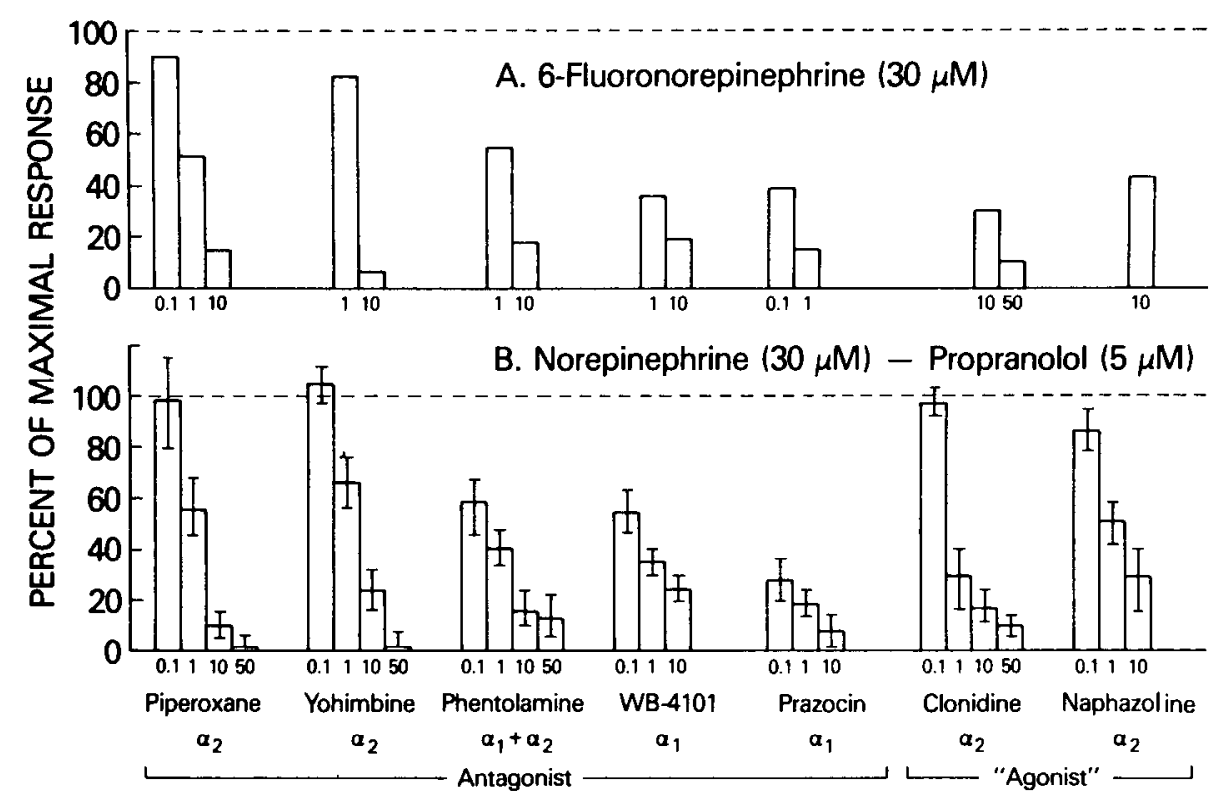

Figure 6. Effect of $\alpha$-adrenergic antagonists on the accumulation of radioactive cyclic AMP elicited by $(A)$ 6-fluoronorepinephrine or $(B)$ a combination of norepinephrine and propranolol in adenine-labeled rat cerebral cortical slices. Slices were incubated for $10 \mathrm{~min}$ with $30 \mu \mathrm{M}$ 6-fluoronorepinephrine or $30 \mu \mathrm{M}$ norepinephrine plus $5 \mu \mathrm{M}$ propranolol in the absence or presence of indicated micromolar concentrations of the $\alpha$-adrenergic antagonists, piperoxan, yohimbine, phentolamine, WB4101, and prazosin, and the so-called "agonists," clonidine and naphazoline, and accumulations of cyclic $\left[{ }^{3} \mathrm{H}\right]$ AMP were measured as detailed under "Materials and Methods." The percent inhibitions of the response to 6-fluoronorepinephrine $(A)$ are averages for two experiments while for norepinephrine-propranolol $(B)$, they are means \pm SEM for three to five experiments.

to $30 \mu \mathrm{M} 2$-fluoronorepinephrine was blocked by $10 \mu \mathrm{M}$ propranolol and partially blocked by $100 \mu \mathrm{M}$ practolol or $100 \mu \mathrm{M}$ butoxamine (Fig. $7 B$ ). A combination of practolol and butoxamine each at $100 \mu \mathrm{M}$ did not cause a complete blockade of the response to 2-fluoronorepinephrine (data not shown). Metoprolol at $10 \mu \mathrm{M}$ caused a $70 \%$ blockade of the response of 2-fluoronorepinephrine. 2-Fluoronorepinephrine is probably a relatively weak $\beta_{2}$-adrenergic agonist (cf., Nimit et al., 1980) so that the blockade by 10 $\mu \mathrm{M}$ metoprolol might be due, in part, to competition at $\beta_{2}$ - rather than $\beta_{1}$-adrenergic receptors.

It appeared possible, since $\alpha$-adrenergic receptors did not activate cyclic AMP-generating systems in cerebellar slices, that such receptors, if present, might be inhibitory as is the case in certain cultured cells of central origin (McCarthy and deVellis, 1978). However, phenylephrine at $100 \mu \mathrm{M}$ did not reduce the response to $10 \mu \mathrm{M}$ isoproterenol in rat cerebellar slices (data not shown). In addition to the apparent lack of involvement of $\alpha$-adrenergic mechanisms in the control of cyclic AMP systems, rat cerebellar slices are unique in exhibiting a significant contribution from $\beta_{2}$-adrenergic receptor mechanisms to the response of cyclic AMP systems to $\beta$-adrenergic agonists. The latter finding is in agreement with binding data indicative of a high proportion of $\beta_{2}$-adrenergic receptors in membranes from this brain region in contrast to other regions where $\beta_{1}$-adrenergic receptors are predominant (Minneman et al., 1979). In cat cerebellar membranes, $\beta_{2}$-adrenergic receptors appeared primarily responsible for activation of adenylate cyclase (Dolphin et al., 1979), as was previously suggested for rabbit cerebellar membranes (Cote and Kebabian, 1978).

Hippocampus. Norepinephrine elicited an accumulation of cyclic AMP in rat hippocampal slices which appeared slightly greater $(p<0.1)$ than the response to 2-fluoronorepinephrine (Fig. 3B). 6-Fluoronorepinephrine elicited a much smaller response and a combination of the two fluoronorepinephrines elicited a response similar to that of norepinephrine. These results were similar to those of cerebral cortex. However, unlike cerebral cortex, the presence of adenosine deaminase did not significantly reduce the response to norepinephrine nor did the deaminase eliminate the response to 6 -fluoronorepinephrine which still elicited a small accumulation of cyclic AMP $(p<0.05)$. It would appear that in this brain region, $\alpha$-adrenergic receptor-mediated responses are not totally dependent on the presence of endogenous adenosine. The response to a combination of adenosine and 6-fluoronorepinephrine was not greater than additive (Fig. 4). However, a combination of norepinephrine and 2-chloroadenosine did appear to elicit a slightly greater than additive response in the presence of adenosine deaminase (Fig. $5, p<0.1$ ). The response to histamine also appeared to be potentiated by 6 -fluoronorepinephrine (Fig. $4, p<0.05$ ). The hippocampal preparation seems to present a situation intermediate between cortex where $\alpha$-adrenergic responses are virtually dependent on adenosine and other brain regions (see below) where $\alpha$-adrenergic and adenosine responses appear virtually independent. The responses to $30 \mu \mathrm{M} 2$ - 

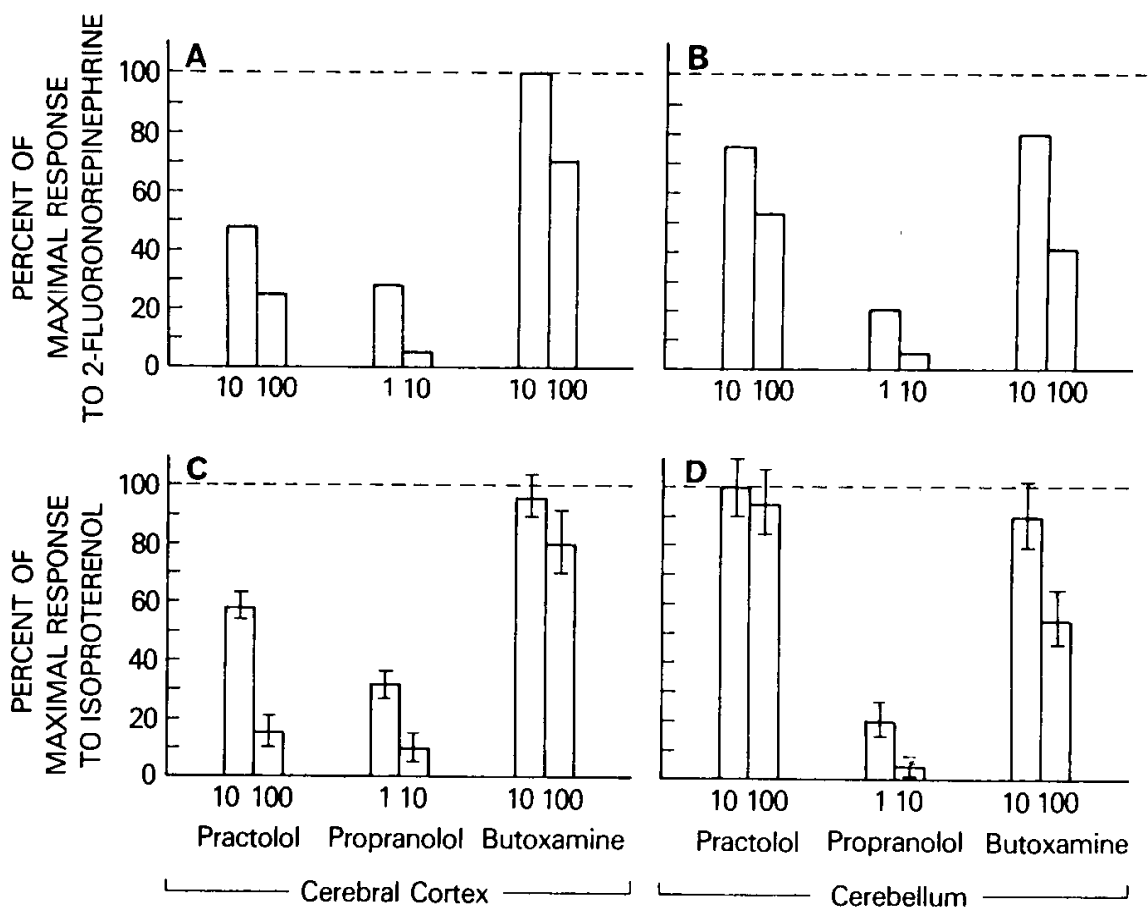

Figure 7. Effect of $\beta$-adrenergic antagonists on the accumulation of radioactive cyclic AMP elicited by 2 -fluoronorepinephrine in adenine-labeled $(A)$ cerebral cortical slices or $(B)$ cerebellar slices or by isoproterenol in adenine-labeled $(C)$ cerebral cortical slices or $(D)$ cerebellar slices. Slices were incubated for $10 \mathrm{~min}$ with $30 \mu \mathrm{M} 2$-fluoronorepinephrine $(A$ and $B$ ) or $10 \mu \mathrm{M}$ isoproterenol $(C$ and $D$ ) in the presence or absence of indicated micromolar concentrations of the $\beta$-adrenergic antagonists, practolol $\left(\beta_{1}\right)$, propranolol $\left(\beta_{1}+\beta_{2}\right)$, and butoxamine $\left(\beta_{2}\right)$, and accumulations of cyclic $\left[{ }^{3} \mathrm{H}\right] \mathrm{AMP}$ were measured as detailed under "Materials and Methods." The percent inhibitions of the response to 2-fluoronorepinephrine $(A$ and $B$ ) are averages for two experiments, while for isoproterenol ( $C$ and $D$ ), they are means \pm SEM for three experiments.

fluoronorepinephrine was completely blocked by propranolol $(10 \mu \mathrm{M})$ and virtually blocked by metoprolol (10 $\mu \mathrm{M})$ in hippocampal slices (data not shown). In cat hippocampal slices, $\beta_{1}$-adrenergic receptors are primarily responsible for activation of adenylate cyclase by catecholamines (Dolphin et al., 1979).

Striatum. Norepinephrine elicited a slightly greater response than 2-fluoronorepinephrine in rat striatal slices especially in the presence of adenosine deaminase (Fig. $3, A$ and $B, p<0.1$ ). 6-Fluoronorepinephrine elicited a very small response which appeared significant only in the presence of adenosine deaminase $(p<0.01)$. A combination of adenosine and 6-fluoronorepinephrine did not elicit a greater than additive response (Fig. 4) nor did a combination of 2 -chloroadenosine and norepinephrine elicit a greater than additive response in the presence of adenosine deaminase (Fig. 5). While neither 6-fluoronorepinephrine or histamine elicited a significant accumulation of cyclic AMP in rat striatal slices, a combination of the two amines elicited a significant accumulation (Fig. $4, p<0.025$ ) which, however, is not greater than what might be expected from additive effects. The striatum thus appears to represent a region in which potentiative interactions of $\alpha$-adrenergic receptors with $\beta$-adrenergic, histaminergic, or adenosine receptor-elicited accumulations of cyclic AMP are absent or are relatively insignificant. Indeed, the $\alpha$-adrenergic response itself was relatively minor in striatal slices.

The response to 2-fluoronorepinephrine $(30 \mu \mathrm{M})$ was completely blocked by propranolol $(10 \mu \mathrm{M})$ and metoprolol $(10 \mu \mathrm{M})$ in rat striatal slices (data not shown). Dopamine did not elicit a significant accumulation of cyclic AMP in striatal slices nor for that matter in slices from any of the eight brain regions (data not shown). Dopamine has been reported to elicit accumulations of cyclic AMP in rat striatal slices, but the presence of a phosphodiesterase inhibitor was requisite (Forn et al., 1974).

Superior colliculi. Norepinephrine elicited a slightly greater response than 2-fluoronorepinephrine in slices of rat superior colliculi, but as in striatum, this difference was significant only in the presence of adenosine deaminase (Fig. 3, $A$ and $B, p<0.1$ ). Adenosine deaminase did appear to reduce the magnitude of the responses to the amines, but the reduction was not significant $(p>0.2)$. 6-Fluoronorepinephrine elicited a small but significant accumulation of cyclic AMP both in the presence and absence of adenosine deaminase $(p<0.1)$. Potentiative interactions between 6-fluoronorepinephrine or norepinephrine and 2-chloroadenosine or histamine were not manifest in slices of superior colliculi (Figs. 4 and 5). Histamine had no effect either in the absence or presence of 6-fluoronorepinephrine. Serotonin also had no effect 
(data not shown) although this brain region has been reported to contain serotonin-sensitive adenylate cyclases (Von Hungen et al., 1974). The response to $30 \mu \mathrm{M}$ 2 -fluoronorepinephrine was blocked by propranolol (10 $\mu \mathrm{M})$ and virtually blocked by the $\beta_{1}$-adrenergic antagonist metoprolol $(10 \mu \mathrm{M})$ in slices of rat superior colliculi (data not shown).

Thalamus. Norepinephrine elicited a relatively small response in rat thalamic slices (Fig. $3, A$ and $B$ ). 2Fluoronorepinephrine and 6-fluoronorepinephrine elicited smaller responses. Adenosine deaminase had little effect on the magnitude of the responses. The response to 6-fluoronorepinephrine was no longer significant in the presence of deaminase $(p>0.2)$ even though the magnitude of the response appeared unaffected. 6-Fluoronorepinephrine did not appear to potentiate responses to histamine or adenosine (Fig. 4) and the response to a combination of norepinephrine and 2-chloroadenosine was not greater than additive (Fig. 5). The response to $30 \mu \mathrm{M} 2$-fluoronorepinephrine was completely blocked by propranolol $(10 \mu \mathrm{M})$ and by the $\beta_{1}$-adrenergic antagonist metoprolol $(10 \mu \mathrm{M})$ in thalamic slices (data not shown).

Hypothalamus. Norepinephrine elicited a significantly greater response in rat hypothalamic slices than did 2fluoronorepinephrine both in the presence of adenosine deaminase $(p<0.01)$ and in its absence $(p<0.05)$ (Fig. $3, A$ and $B$ ). The response to norepinephrine appeared to be slightly reduced by the presence of deaminase, but this apparent reduction was not found to be significant $(p>0.2)$. The response to 6-fluoronorepinephrine was small but significant both in the presence and absence of adenosine deaminase $(p<0.01)$. In hypothalamic slices, a potentiative interaction of 6-fluoronorepinephrine and 2-fluoronorepinephrine was clearly manifest (Fig. 3, A and $B, p<0.05$ ). 6-Fluoronorepinephrine did not, however, potentiate the response to adenosine in hypothalamic slices (Fig. 4) and the response to a combination of norepinephrine and 2-chloroadenosine was merely additive (Fig. 5). Histamine had no effect on cyclic AMP levels in either the absence or presence of adenosine deaminase. It would appear that in hypothalamus, as in striatum, superior colliculi, and thalamus, that $\alpha$-adrenergic mechanisms are not linked to a major extent with adenosine responses. The hypothalamus is unique in being the only brain region in which potentiative interactions between $\alpha$-adrenergic and $\beta$-adrenergic mechanisms were found to be significant. This may well explain a prior report that either $\alpha$ - or $\beta$-adrenergic antagonists completely blocked responses to catecholamines in hypothalamic slices (Palmer et al., 1973). However, while the response to $30 \mu \mathrm{M}$ 2-fluoronorepinephrine was inhibited $90 \%$ by $10 \mu \mathrm{M}$ metoprolol, prazosin $(10 \mu \mathrm{M})$ had virtually no effect on the response (data not shown).

Medulla-pons. Norepinephrine, 2-fluoronorepinephrine, and 6-fluoronorepinephrine elicited accumulations of cyclic AMP in slices of rat medulla-pons (Fig. 3, $A$ and $B$ ). Remarkably, in slices of this brain region, the presence of adenosine deaminase appeared to increase rather than decrease responses to the amines. Although this apparent increase was not found to be significant ( $p$ $>0.2$ ), it is under further investigation. A histamine response was also manifest in slices of medulla-pons, both in the absence (Fig. 4) and in the presence (data not shown) of adenosine deaminase. In other brain regions in which a small but significant response to histamine was detected, namely cortex, hippocampus, and thalamus (Fig. $4, p<0.025$ ), the presence of adenosine deaminase blocked the response (data not shown). In slices of medulla-pons, the response to histamine actually appeared slightly greater in the presence of adenosine deaminase. The slices from medulla-pons are also somewhat exceptional in that adenosine deaminase does not cause a reduction in basal levels of cyclic AMP. Adenosine deaminase also had no effect on basal levels of cyclic AMP in slices of superior colliculi. In other regions, the presence of adenosine deaminase tends to cause (striatum, thalamus, hypothalamus) or clearly causes (cortex, cerebellum, hippocampus) a reduction in basal levels of cyclic AMP. No indications of potentiative interactions among adenosine, histamine, and catecholamines were manifest in slices from rat medulla-pons (Figs. 4 and 5).

The response to $30 \mu \mathrm{M}$ 2-fluoronorepinephrine was completely blocked by propranolol $(10 \mu \mathrm{M})$ and metoprolol $(10 \mu \mathrm{M})$ in slices of medulla-pons, while the response to $30 \mu \mathrm{M}$ 6-fluoronorepinephrine was inhibited $75 \%$ with $10 \mu \mathrm{M}$ prazosin (data not shown).

\section{Discussion}

The nature of receptors which activate cyclic AMPgenerating systems has been surveyed in slices from eight rat brain regions and possible potentiative interactions between such receptor mechanisms have been probed. It is clear that in all eight brain regions, $\beta$-adrenergic receptors and adenosine receptors activate marked accumulations of cyclic AMP. The $\beta$-adrenergic receptor-mediated responses appear to involve predominantly $\beta_{1^{-}}$ adrenergic mechanisms except in cerebellum where $\beta_{2^{-}}$ adrenergic mechanisms make a significant contribution to the response. The selectivity of $\beta_{1}$ and $\beta_{2}$-adrenergic antagonists (practolol, metoprolol, butoxamine, IPS 339) did not appear sufficient (J. W. Daly, W. Padgett, C. R. Creveling, D. Cantacuzene, and K. L. Kirk, unpublished data) to easily quantitate the relative contributions of $\beta_{1^{-}}$and $\beta_{2}$-adrenergic mechanisms to the response of cyclic AMP systems in cerebral cortical and cerebellar slices.

Activation of $\alpha$-adrenergic receptors elicits small but significant accumulations of cyclic AMP in all brain regions except cerebellum. The $\alpha$-adrenergic response is very small in striatum. In rat cerebral cortex, the $\alpha$ adrenergic response clearly exhibits $\alpha_{1}$-adrenergic character (cf., Skolnick et al., 1978). Prazosin, a highly specific $\alpha_{1}$-adrenergic antagonist, also blocked responses to 6fluoronorepinephrine in medulla-pons. Characterization of the very small response to $30 \mu \mathrm{M}$ 6-fluoronorepinephrine in other brain regions proved difficult. Recently it has been reported that in certain rat brain stem nuclei, the epinephrine response is very effectively blocked by phentolamine and by the $\alpha_{2}$-adrenergic antagonist yohimbine (Wilkening et al., 1980). In rat spinal cord, the $\alpha$-adrenergic component of the norepinephrine response is effectively blocked by $\alpha_{1}$ - but not by $\alpha_{2}$-adrenergic antagonists (Jones and McKenna, 1980b). Further char- 
acterization of the nature of the $\alpha$-adrenergic response in different brain regions will be necessary.

Histamine elicits small but significant accumulations of cyclic AMP in medulla-pons > hippocampus, thalamus, and cortex. In the last three regions, the histamine response is no longer significant $(p>0.2)$ in the presence of adenosine deaminase (data not shown). The nature of the responses to histamine have not been investigated and indeed such responses contrast with some reports on the lack of histamine responses in slices from rat brain (see Daly, 1977). A histamine response has been reported for rat hippocampal slices (Dismukes et al., 1976). Dopamine and serotonin had no significant effect in any brain region (data not shown).

Potentiative interactions between adenosine and amines are clearly evident only in cerebral cortical slices, where $\alpha$-adrenergic receptor activation augments the adenosine responses. Indeed, the $\alpha$-adrenergic response appears virtually dependent on adenosine in rat cerebral cortical slices (Table III). In this region, potentiative interactions between $\alpha$-adrenergic agonists and histamine (Fig. 4 ) and between $\alpha$-adrenergic and $\beta$-adrenergic agonists (Fig. $3 B$ ) also appear to pertain. In other brain regions, potentiative interactions between amines and adenosine are not clearly manifest except for the response to a combination of norepinephrine and 2-chloroadenosine in hippocampal slices. It appears that adenosine is not requisite to $\alpha$-adrenergic responses in brain regions other than cerebral cortex. Whether other substances such as peptides (cf., Quik et al., 1978) or prostaglandins (cf., Dismukes and Daly, 1975; Partington et al., 1980) may be requisite for the $\alpha$-adrenergic responses in subcortical tissue is worthy of investigation. It has been reported recently that $\alpha$-adrenergic receptor-mediated accumulations of cyclic AMP in rat spinal cord slices are independent of adenosine (Jones and McKenna, 1980b). Adenosine and histamine interactions were not investigated in detail, but the adenosine response in cortex, hippocampus, and thalamus appeared to be significantly potentiated by histamine while in medulla-pons, the response to an adenosine-histamine combination was not greater than additive (data not shown). In other regions, histamine had no effect in the absence or presence of adenosine. Serotonin did not significantly affect the adenosine response in any brain region (data not shown). Potentiative amine-amine interactions were also not clearly manifest in brain regions other than cerebral cortex with the exception of a potentiative interaction of the $\alpha$-adrenergic agonist and histamine in hippocampal slices and a potentiative interaction of $\alpha$ - and $\beta$-adrenergic agonists in hypothalamic slices. The present data indicate that potentiative interactions of biogenic amines with adenosine and of amines with other amines do not occur uniformly throughout brain and may well represent subtle and important control mechanisms at only certain sites of the central nervous system.

\section{References}

Badger, T. M., and T. J. Cicero (1977) Norepinephrine-sensitive adenylate cyclase in rat hypothalamus: Effects of adrenergic blockers and narcotics. Res. Commun. Chem. Pathol. Pharmacol. 18: 175-188.

Chasin, M., I. Rivkin, F. Mamrak, G. Samaniego, and S. M.
Hess (1971) $\alpha$ - and $\beta$-Adrenergic receptors as mediators of accumulation of cyclic adenosine $3^{\prime}, 5^{\prime}$-monophosphate in specific areas of guinea pig brain. J. Biol. Chem. 246: 3037-3041.

Chasin, M., F. Mamrak, S. G. Samaniego, and S. M. Hess (1973) Characteristics of the catecholamine and histamine receptor sites mediating accumulation of cyclic adenosine $3^{\prime}, 5^{\prime}$-monophosphate in guinea pig brain. J. Neurochem. 21: 1415-1427.

Cote, T. E., and J. W. Kebabian (1978) Beta-adrenergic receptor in the brain: Comparison of ${ }^{3} \mathrm{H}$-dihydroalprenolol binding sites and a beta-adrenergic receptor regulating adenylyl cyclase activity in cell free homogenates. Life Sci. 23: 17031713.

Daly, J. W. (1977) Cyclic Nucleotides in the Nervous System, Plenum Press, New York.

Daly, J. W., W. Padgett, Y. Nimitkitpaisan, C. R. Creveling, D. Cantacuzene, and K. L. Kirk (1980) Fluoronorepinephrines: Specific agonists for the activation of alpha and beta adrenergic-sensitive cyclic AMP-generating systems in brain slices. J. Pharmacol. Exp. Ther. 212: 382-389.

Dismukes, K., and J. W. Daly (1975) Accumulation of adenosine $3^{\prime}, 5^{\prime}$-monophosphate in rat brain slices: Effects of prostaglandins. Life Sci. 17: 199-210.

Dismukes, R. K., P. Ghosh, C. R. Creveling, and J. W. Daly (1976) Norepinephrine depletion and responsiveness of norepinephrine-sensitive cortical cyclic AMP-generating systems in guinea pig brain. Exp. Neurol. 52: 206-215.

Dolphin, A., M. Hamont, and J. Bockaert (1979) The resolution of dopamine and $\beta_{1^{-}}$and $\beta_{2}$-adrenergic-sensitive adenylate cyclase activities in homogenates of cat cerebellum, hippocampus and cerebral cortex. Brain Res. 179: 305-319.

Ferrendelli, J. A., D. A. Kinscherf, and M.- M. Chang (1975) Comparison of the effects of biogenic amines of cyclic GMP and cyclic AMP levels in mouse cerebellum in vitro. Brain Res. 84: 63-73.

Forn, J., B. K. Krueger, and P. Greengard (1974) Adenosine $3^{\prime}, 5^{\prime}$-monophosphate content in rat caudate nucleus: Demonstration of dopaminergic and adrenergic receptors. Science 186: 1118-1120.

Harris, J. E. (1976) $\beta$-Adrenergic receptor-mediated adenosine cyclic $3^{\prime}, 5^{\prime}$-monophosphate accumulation in the rat corpus striatum. Mol. Pharmacol. 12: 546-558.

Horn, A. S., and O. T. Phillipson (1976) A noradrenaline sensitive adenylate cyclase in the rat limbic forebrain: Preparation, properties and the effects of agonists, adrenolytics and neuroleptic drugs. Eur. J. Pharmacol. 37: 1-11.

Huang, M., A. K. S. Ho, and J. W. Daly (1973) Accumulation of adenosine cyclic $3^{\prime}, 5^{\prime}$-monophosphate in rat cerebral cortical slices: Stimulatory effect of alpha and beta adrenergic agents after treatment with 6-hydroxydopamine, 2,3,5-trihydroxyphenethylamine and dihydroxytryptamines. Mol. Pharmacol. 9: 711-717.

Jones, D. J., and L. F. McKenna (1980a) Norepinephrine-stimulated cyclic AMP formation in rat spinal cord. J. Neurochem. 34: 467-469.

Jones, D. L., and L. F. McKenna (1980b) Alpha adrenergic receptor mediated formation of cyclic AMP in rat spinal cord. J. Cyclic Nucleotide Res., 6: 133-141.

Kakiuchi, S., and T. W. Rall (1968) 'The influence of chemical agents on the accumulation of adenosine $3^{\prime}, 5^{\prime}$-phosphate in slices of rabbit cerebellum. Mol. Pharmacol. 4: 357-378.

Kirk, K. L., D. Cantacuzene, Y. Nimitkitpaisan, D. H. McCulloh, W. L. Padgett, J. W. Daly, and C. R. Creveling (1979) Synthesis and biological properties of 2-, 5-, and 6-fluoronorepinephrines. J. Med. Chem. 22: 1493-1497.

Kodama, T., Y. Matsukado, and H. Shimizu (1973) The cyclic AMP system of human brain. Brain Res. 50: 135-146.

Langer, S. Z. (1977) Presynaptic receptors and their role in the regulation of transmitter release. Br. J. Pharmacol. 60: 481487. 
Leclerc, G., A. Mann, C.-G. Wermuth, N. Bieth, and J. Schwartz (1977) Synthesis and $\beta$-adrenergic blocking activity of a novel class of aromatic oxime ethers. J. Med. Chem. 20: 1657-1662.

Lowry, O. H., N. J. Rosebrough, A. L. Farr, and R. J. Randall (1951) Protein measurement with the Folin phenol reagent. J. Biol. Chem 193: 265-275.

McCarthy, K. D., and J. deVellis (1978) Alpha-adrenergic receptor modulation of beta-adrenergic, adenosine, and prostaglandin $\mathrm{E}_{1}$ increased adenosine $3^{\prime}: 5^{\prime}$-cyclic monophosphate levels in primary cultures of glia. J. Cyclic Nucleotide Res. 4: 15-26.

Miller, G. L. (1959) Protein determination for large numbers of samples. Anal. Chem. 31: 964.

Minneman, K. P., L. R. Hegstrand, and P. B. Molinoff (1979) Simultaneous determination of $\beta-1$ and $\beta$-2-adrenergic receptors in tissues containing both receptor subtypes. Mol. Pharmacol. 16: 34-46.

Mobley, P. L., and F. Sulser (1970) norepinephrine stimulated cyclic AMP accumulation in rat limbic forebrain slices: Partial mediation by a subpopulation of receptors with neither $\alpha$ nor $\beta$ characteristics. Eur. J. Pharmacol. 60: 221-228.

Nahorski, S. R., and B. M. Smith (1977) Characteristics of chick cerebral $\beta$-adrenoceptors assessed by cyclic adenosine $3^{\prime}, 5^{\prime}$ monophosphate formation and $\left[{ }^{3} \mathrm{H}\right]$-propranolol binding. Naunyn-Schmiedebergs Arch. Pharmacol. 298: 23-28.

Nahorski, S. R., K. J. Rogers, and C. Edwards (1975) Cerebral glycogenolysis and stimulation of $\beta$-adrenoreceptors and histamine $\mathrm{H}_{2}$ receptors. Brain Res. 54: 255P-256P.

Nimit, Y., D. Cantacuzene, K. L. Kirk, C. R. Creveling, and J. W. Daly (1980) The binding of fluorocatecholamines to adrenergic and dopaminergic receptors in rat brain membranes. Life Sci. 27: 1577-1585.

Palmer, G. C., F. Sulser, and G. A. Robison (1973) Effects of neurohumoral and adrenergic agents on cyclic AMP levels in various areas of the rat brain in vitro. Neuropharmacology 12: 327-337.

Partington, C. R., M. W. Edwards, and J. W. Daly (1980) Regulation of cyclic AMP formation in brain tissue by $\alpha$ adrenergic receptors: Requisite intermediacy of prostaglandins of the E series. Proc. Natl. Acad. Sci. U. S. A. 77: 30243028.

Perkins, J. P., and M. M. Moore (1973) Characterization of the adrenergic receptors mediating a rise in cyclic $3^{\prime}, 5^{\prime}$-adenosine monophosphate in rat cerebral cortex. J. Pharmacol. Exp. Ther. 185: 371-378.

Quik, M., L. L. Iversen, and S. R. Bloom (1978) Fiffect of vasoactive intestinal peptide (VIP) and other peptides on cAMP accumulation in rat brain. Biochem. Pharmacol. 27: 2209-2213.

Sabol, S. L., and M. Nirenberg (1979) Regulation of adenylate cyclase of neuroblastoma $\times$ glioma hybrid cells by $\alpha$-adrenergic receptors. I. Inhibition of adenylate cyclase mediated by $\alpha$ receptors. J. Biol. Chem. 254: 1913-1920.

Salomon, Y., C. Londos, and M. Rodbell (1974) A highly sensitive adenylate cyclase assay. Anal. Biochem. 58: 541-548.

Sattin, A., T. W. Rall, and J. Zanella (1975) Regulation of cyclic adenosine $3^{\prime}, 5^{\prime}$-monophosphate levels in guinea-pig cerebral cortex by interaction of alpha adrenergic and adenosine receptor activity. J. Pharmacol. Exp. Ther. 192: 22-32.

Schultz, J., and J. W. Daly (1973a) Accumulation of cyclic adenosine $3^{\prime}, 5^{\prime}$-monophosphate in cerebral cortical slices from rat and mouse stimulatory effect of $\alpha$ - and $\beta$-adrenergic agents and adenosine. J. Neurochem. 21: 1319-1326.

Schultz, J., and J. W. Daly (1973b) Adenosine 3',5'-monophosphate in guinea pig cerebral cortical slices: Effects of $\alpha$ - and $\beta$-adrenergic agents, histamine, serotonin and adenosine. J. Neurochem. 21: 573-579.

Schwabe, U, and J. W. Daly (1977) The role of calcium ions in accumulations of cyclic adenosine monophosphate elicited by alpha and beta adrenergic agonists in rat brain slices. J. Pharmacol. Exp. Ther. 202: 134-143.

Shimizu, H., J. W. Daly, and C. R. Creveling (1969) A radioisotopic method for measuring the formation of adenosine $3^{\prime}$ 5 '-cyclic monophosphate in incubated slices of brain. J. Neurochem. 16: 1609-1619.

Skolnick, P., and J. W. Daly (1975) Stimulation of adenosine $3^{\prime}, 5^{\prime}$-monophosphate formation by alpha and beta adrenergic agonists in rat cerebral cortical slices: Effects of clonidine. Mol. Pharmacol. 11: 545-551.

Skolnick, P., and J. W. Daly (1976) Antagonism of $\alpha$ - and $\beta$ adrenergic-mediated accumulations of cyclic AMP in rat cerebral cortical slices by the $\beta$-antagonist, (-)alprenolol. Life Sci. 19: 497-504.

Skolnick, P., J. W. Daly, R. Freedman, and B. J. Hoffer (1976) Interrelationship between catecholamine-stimulated formation of cyclic AMP in cerebellar slices and inhibitory effects on cerebellar Purkinje cells: Antagonism by neuroleptic compounds. J. Pharmacol. Exp. Ther. 197: 280-292.

Skolnick, P., L. P. Stalvey, J. W. Daly, E. Hoyler, and J. N. Davis (1978) Binding of $\alpha$-and $\beta$-adrenergic ligands to cerebral cortical membranes: Effect of 6-hydroxydopamine treatment and relationship to the responsiveness of cyclic AMPgenerating systems in two rat strains. Eur. J. Pharmacol. 47: 201-210.

U'Prichard, D. C., D. A. Greenberg, and S. H. Snyder (1977) Binding characteristics of a radiolabeled agonist and antagonist at central nervous system alpha noradrenergic receptors. Mol. Pharmacol. 13: 454-473.

U'Prichard, D. C., D. B. Bylund, and S. H. Snyder (1978a) $( \pm)-\left[{ }^{3} \mathrm{H}\right]$ Epinephrine and $(-)-\left[{ }^{3} \mathrm{H}\right]$ dihydroalprenolol binding to $\beta_{1}$ - and $\beta_{2}$-noradrenergic receptors in brain, heart, and lung membranes. J. Biol. Chem. 253: 5090-5102.

U'Prichard, D. C., M. E. Charness, D. Robertson, and S. H. Snyder (1978b) Prazosin: Differential affinities for two populations of $\alpha$-noradrenergic receptor binding sites. Eur. J. Pharmacol. 50: 87-89.

Vetulani, J., N. J. Leith, R. J. Stawarz, and F. Sulser (1977) Effect of clonidine on the noradrenergic cyclic AMP generating system in the limbic forebrain and on medial forebrain bundle self-stimulation behavior. Experientia 33: 1490-1491.

Von Hungen, K., S. Roberts, and D. F. Hill (1974) Developmental and regional variations in neurotransmitter-sensitive adenylate cyclase systems in cell-free preparations from rat brain. J. Neurochem. 22: 811-819.

Weissman, B. A., J. W. Daly, and P. Skolnick (1975) Diethylstilbestrol-elicited accumulation of cyclic AMP in incubated rat hypothalamus. Endocrinology 97: 1559-1566.

Wilkening, D., B. Dvorkin, M. H. Makman, J. Y. I.ew, J. Matsumoto, Y. Baba, M. Goldstein, and K. Fuxe (1980) Catecholamine-stimulated cyclic AMP formation in phenylethanolamine $N$-methyltransferase containing brain stem nuclei of normal rats and of rats with spontaneous genetic hypertension. Brain Res. 186: 133-144. 